DOI: http://dx.doi.org/10.33846/hn20710

http://heanoti.com/index.php/hn

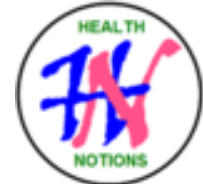

RESEARCH ARTICLE

URL of this article: http://heanoti.com/index.php/hn/article/view/hn20710

\title{
Personal Hygiene, Environmental Sanitation and Hepatitis A Infections in
} Universitas Jember

\author{
Dian Septivita $^{1(\mathrm{CA})}$, Isa Ma'rufi², Farida Wahyu Ningtyias ${ }^{3}$ \\ ${ }^{1(\mathrm{CA})}$ Postgraduate School of Public Health Science, Universitas Jember, Indonesia; dseptivita@gmail.com \\ (Corresponding Author) \\ ${ }^{2}$ Faculty of Public Health, Universitas Jember, Indonesia; isa.marufi@ gmail.com \\ ${ }^{3}$ Faculty of Public Health, Universitas Jember
}

\begin{abstract}
Hepatitis A is a disease caused by type A hepatitis virus that attacks human liver cells. The disease is closely related to the lack of clean water, inadequate sanitation and poor personal hygiene. Hepatitis A can lead to the incidence of widespread public health problems and cause outbreaks. The purpose of this study was to analyze the effect of personal hygiene and environmental sanitation on the incidence of hepatitis A at Universitas Jember. The researcher used observational analytics research design with case-control approach. A total of 92 respondent consisting of case and control respondents was taken as samples. Case sample selected by using simple random sampling, and control sample selected by using purposive sampling. The data were analyzed by using Chi-square test. The results showed that personal hygiene had an effect on the incidence of hepatitis A with p-value of 0.000 , while environmental sanitation had no effect with p-value of 0.402 . There is a need to enhance the active role of health workers in providing health promotion means in schools, such as routine health counseling to improve students' knowledge about hepatitis A and the way to prevent the disease through behavior improvement.
\end{abstract}

Keywords: hepatitis A virus; personal hygiene; sanitation

\section{INTRODUCTION}

Hepatitis A virus can be transmitted through food or drink that contaminated by an infected person feces (stool) and then entering a person's mouth ${ }^{(1)}$. Hepatitis A disease is one of the mildest and most prevalent cases of hepatitis in the world, and can lead to widespread public health problems and can lead to outbreaks ${ }^{(2)}$. According to basic health research data, hepatitis prevalence in 2013 is $1.2 \%$, increased two times higher than in 2007 at $0.6 \%$. The tendency of hepatitis in East Java according to Riskesdas Results in 2013 is $1 \%$, higher than in the 2007 at $0.3 \%$.

In 2002-2003, there were Hepatitis A outbreaks in Jember Regency and $80 \%$ of patients were students. In 2006, Public health office of Jember District again declare Hepatitis A outbreaks. In January 2012, there were 50 people who suffer from Hepatitis A, and there were 70 people on February to early March ${ }^{(3)}$. Data obtained from students with Hepatitis A showed that $56 \%$ of the students used to eat in stalls or street vendors with poor hygiene sanitation ${ }^{(4)}$. This is allegedly due to eating out habits (because most of the patients live in boarding house or dormitory), which in fact most of the food vendor hygiene sanitation is still questionable ${ }^{(5)}$. According to medical record data related to the hepatitis A infection cases in Unit Medical Center Jember University showed that in 2014 there were 17 cases, in 2015 were 21 cases, in 2016 the case were increased to 63 cases, and were decrease to 54 cases in 2017.

Manual of viral hepatitis control stated that poor environmental conditions have an effect on the incidence of hepatitis $\mathrm{A}^{(2)}$. That environmental conditions including the lack of clean water supply, poor waste disposal, and poor personal hygiene sanitation. According to the epidemiological triangle, host factor (personal hygiene) is affected by age, sex, family history and occupational history, the using of unprotected drinking

766| Publisher: Humanistic Network for Science and Technology 
water, the way to get food or drink, clean and healthy living behaviors, washing hands with water and soap, and sexual behaviour deviation/homosexual. Environmental factors are influenced by climate / season / inspection time, environmental sanitation, bathroom and latrines ownership, waste water management, the presence of waste bins, the number of eating places / street vendors / stalls and population density ${ }^{(3)}$.

Personal hygiene is one of the significant risk factors in the incidence of hepatitis A. In a study conducted by Sasoka (2014) showed that people with poor personal hygiene have a greater risk of hepatitis A than someone with good hygiene ${ }^{(5)}$. In this study, researchers used additional methods by using Geographic Information System (GIS).

The purpose of this study was to analyze the effect of personal hygiene and environmental sanitation on the incidence of hepatitis A at the Jember University.

\section{METHODS}

The researcher used observational analytics research design with case control approach. A total of 92 respondent consisting of case and control respondents was taken as samples. Case sample selected by using simple random sampling, and control sample selected by using purposive sampling. The data were analyzed by using Chi square test.

\section{RESULTS}

\section{Relationship Between Respondent Characteristics with Hepatitis A Incidence}

The analysis of the relation between respondent characteristic and hepatitis A incidence is as follows.

Table 1. Relationship between respondent characteristics with hepatitis a occurrence

\begin{tabular}{|c|c|c|c|c|c|c|c|}
\hline \multirow{2}{*}{$\begin{array}{l}\text { Characteristics } \\
\text { of respondents }\end{array}$} & \multirow[t]{2}{*}{ Classification } & \multicolumn{2}{|c|}{ Case } & \multicolumn{2}{|c|}{ Control } & \multirow[t]{2}{*}{ Total } & \multirow{2}{*}{$\begin{array}{c}\text { The } \\
\text { p-value }\end{array}$} \\
\hline & & Frequency & $\%$ & Frequency & $\%$ & & \\
\hline \multirow{3}{*}{ Age } & $12-16$ years old & 1 & 2.2 & 0 & 0 & 1 & 0.315 \\
\hline & $17-25$ years old & 45 & 97.8 & 46 & 100 & 91 & \\
\hline & Total & 46 & 100 & 46 & 100 & 92 & \\
\hline \multirow{3}{*}{ Gender } & Male & 33 & 71.7 & 33 & 71.7 & 66 & 1.000 \\
\hline & Female & 13 & 28.3 & 13 & 28.3 & 26 & \\
\hline & Total & 46 & 100 & 46 & 100 & 92 & \\
\hline \multirow[t]{2}{*}{ Education } & $\begin{array}{l}\text { Highschool } \\
\text { graduate }\end{array}$ & 46 & 100 & 46 & 100 & 92 & - \\
\hline & Total & 46 & 100 & 46 & 100 & 92 & \\
\hline \multirow{15}{*}{ Faculty } & Literature & 2 & 4.3 & 2 & 4.3 & 4 & 1.000 \\
\hline & Economics & 5 & 10.9 & 5 & 10.9 & 10 & \\
\hline & Laws & 1 & 2.2 & 1 & 2.2 & 2 & \\
\hline & Teacher & 9 & 19.6 & 9 & 19.6 & 18 & \\
\hline & Education & & & & & & \\
\hline & $\begin{array}{l}\text { Political and } \\
\text { social science }\end{array}$ & 2 & 4.3 & 2 & 4.3 & 4 & \\
\hline & $\begin{array}{l}\text { Mathemathics } \\
\text { and natural } \\
\text { science }\end{array}$ & 3 & 6.5 & 3 & 6.5 & 6 & \\
\hline & Agriculture & 9 & 19.6 & 9 & 19.6 & 18 & \\
\hline & Technics & 8 & 17.4 & 8 & 17.4 & 16 & \\
\hline & Pharmacy & 1 & 2.2 & 1 & 2.2 & 2 & \\
\hline & $\begin{array}{l}\text { Agriculture } \\
\text { technics }\end{array}$ & 1 & 2.2 & 1 & 2.2 & 2 & \\
\hline & Medical & 1 & 2.2 & 1 & 2.2 & 2 & \\
\hline & Dentistry & 1 & 2.2 & 1 & 2.2 & 2 & \\
\hline & Nursing & 3 & 6.5 & 3 & 6.5 & 6 & \\
\hline & Total & 46 & 100 & 46 & 100 & 92 & \\
\hline \multirow{2}{*}{ Immunization } & Never & 46 & 100 & 46 & 100 & 92 & - \\
\hline & Total & 46 & 100 & 46 & 100 & 92 & \\
\hline
\end{tabular}

767| Publisher: Humanistic Network for Science and Technology 
Bivariate analysis test result using Chi-Square test showed that variable age in case group and control group respondent characteristics had p-value of 0.315 , so that age did not qualify to become one of variables in modeling multivariate test. Variable gender had p-value of 1.000, so that gender did not qualify to become one of variables in modeling multivariate test. The education of all respondents is high school graduated, bivariate test results show that this variable had p-value of "_" , since the resulting data was constant, so that eduaction did not qualify to be one of the variables in the multivariate test modeling.

Repondent characteristic based on faculty showed that this variable had p-value of 1.000 , so that faculty did not qualify to be one of the variables in multivariate test modeling. All of the respondent never got hepatitis A immunization, this variable had p-value of “_" , so that immunization status did not qualify to be one of the variables in the multivariate test modeling.

An analysis of the relationship between knowledge level with hepatitis A incidence in case and control groups was described in the table 2.

Table 2. Relationship between knowledge level with hepatitis A

\begin{tabular}{lcccccc}
\hline \multirow{2}{*}{ Category } & \multicolumn{2}{c}{ Case } & \multicolumn{2}{c}{ Control } & Total & p-value \\
\cline { 2 - 5 } & Frequency & $\%$ & Frequency & $\%$ & & \\
\hline Good & 21 & 45.7 & 35 & 76.1 & 56 & 0.003 \\
Moderate & 25 & 54.3 & 11 & 23.9 & 36 & \\
Total & 46 & 100 & 46 & 100 & 92 & \\
\hline
\end{tabular}

Based on the table 2, bivariate test result using Chi-Square test shows that variable knowledge level had p-value of 0.003 , so that it was qualified to be one of variables in multivariate test modeling.

An analysis of the relationship between personal hygiene and environmental sanitation with the incidence of hepatitis A in case and control groups was described in the table 3.

Table 3. Relationship between personal hygiene and environmental sanitation of students with hepatitis A incidence

\begin{tabular}{|c|c|c|c|c|c|c|c|}
\hline \multirow[t]{2}{*}{ Variable } & \multirow[t]{2}{*}{ Category } & \multicolumn{2}{|c|}{ Case } & \multicolumn{2}{|c|}{ Control } & \multirow[t]{2}{*}{ Total } & \multirow[t]{2}{*}{ p-value } \\
\hline & & Frequency & $\%$ & Frequency & $\%$ & & \\
\hline \multirow{4}{*}{$\begin{array}{l}\text { Personal } \\
\text { hygiene }\end{array}$} & Good & 0 & 0,0 & 1 & 2.2 & 1 & $0.000^{*}$ \\
\hline & Moderate & 12 & 26.1 & 30 & 65.2 & 42 & \\
\hline & Poor & 34 & 73.9 & 15 & 32.6 & 49 & \\
\hline & Total & 46 & 100 & 46 & 100 & 92 & \\
\hline \multirow{4}{*}{$\begin{array}{l}\text { Enviromental } \\
\text { sanitation }\end{array}$} & Good & 27 & 58.7 & 23 & 50 & 50 & 0.402 \\
\hline & Moderate & 19 & 41.3 & 23 & 50 & 42 & \\
\hline & Poor & 46 & 100 & 46 & 100 & 92 & \\
\hline & Total & & & & & & \\
\hline
\end{tabular}

Based on the table 3, bivariate test result on personal hygiene variable by using Chi-Square test showed that this variable had p-value of 0.000 , so that personal hygiene qualifies to be one variable in multivariate test modeling. Bivariate test result using Chi-Square test on students' environmental sanitation variables showed that this variable had p-value of 0.402 , so that it did not qualified to be one of variables in multivariate test modeling.

Summary of multivariate analysis results using SPSS can be seen in Table 4.

Table 4. Multivariate test results

\begin{tabular}{cccccc}
\hline No & Independent variable & B & p-value & OR & 95\% CI \\
\hline 1 & Knowledge level & -1.554 & 0.003 & 0.211 & $0.076<$ OR $<0.590$ \\
\hline 2 & Personal hygiene & -1.939 & 0.000 & 0.144 & $0.053<$ OR < 0.387 \\
\hline Constant & 7.064 & & & \\
\hline
\end{tabular}

Based on multivariate test result, there were two variables that had effect on the incidence of Hepatitis A. These variables were knowledge $(\mathrm{p}=0.003$ with $\mathrm{CI} 0.076<\mathrm{OR}<0.590)$ and personal hygiene $(\mathrm{p}=0.000$ with CI $0.053<\mathrm{OR}<0.387$ ) 


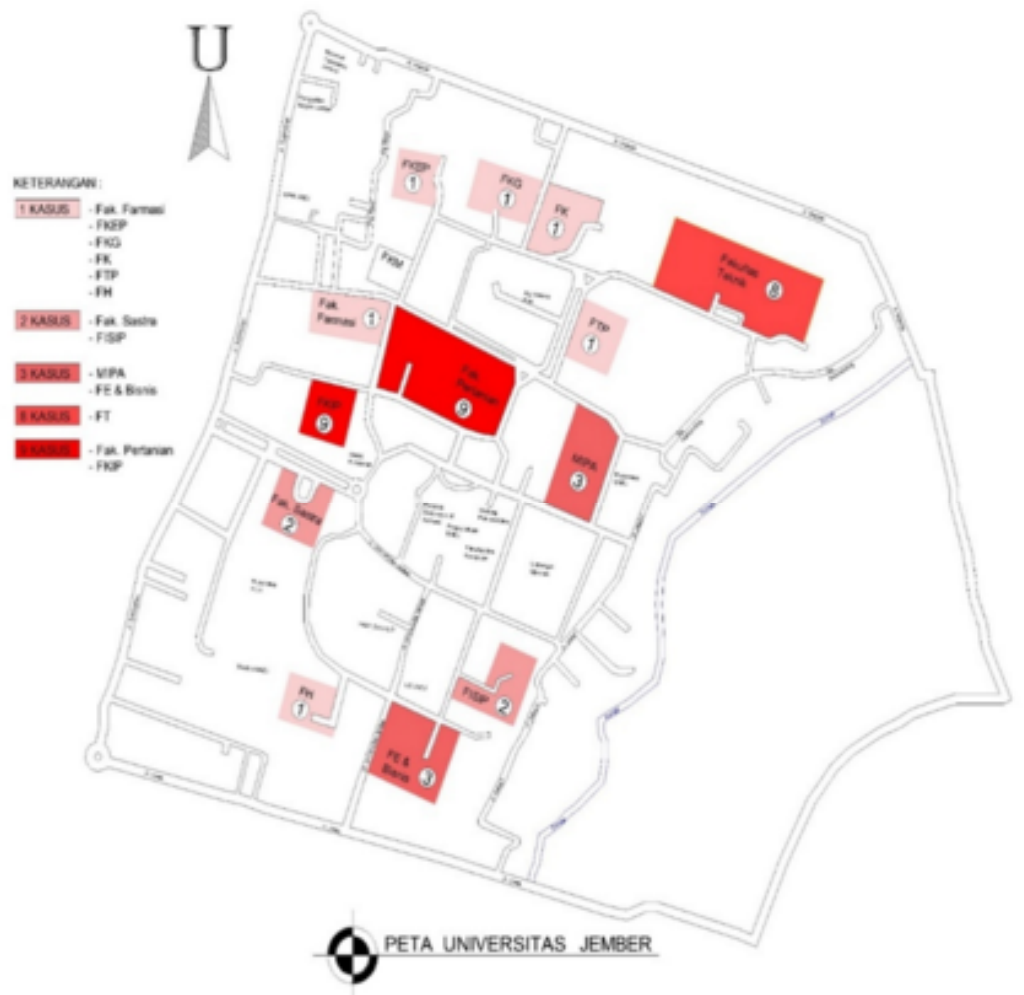

Figure 1. Hepatitis A distribution map

The distribution of hepatitis A incidence at Universitas Jember is marked by bright red to pink area. Area with bright red color had highest hepatitis A incidence, that was teacher education faculty and agriculture faculty as much as 9 cases. Meanwhile the area with pink color had lowest incidence, that was laws, pharmacy agricultural engineering, medical, dentistry, and nursing science faculty that had only one case. Engineering faculty had 8 cases, economics faculty had 5 cases, mathematics and natural sciences faculty had three cases, social and political faculty had two cases.

\section{DISCUSSION}

Based on the bivariate analysis result by using chi square on the table 1 noted that the characteristics of the students have no effect on the incidence of hepatitis A. Human aged 17-25 years are on the late adolescence stage, where mental ability have reach ability to learn and adjust to new situations ${ }^{(6)}$. In this research, there are no difference on the age distribution in cases and control. Many cases of hepatitis A affects Jember University students in late adolescence, that is the age commonly taken by students at college.

Gender can differentiate behavior and characteristic outcomes of behavior ${ }^{(7)}$. Gender is not a key determinant in relation to the hepatitis A incidence. There are other factors than gender such as personal hygiene and environmental sanitation.

All respondents in this study were graduated from high school / equivalent and are studying in college. A person level of knowledge is influenced by education level, the higher the education of a person, the more easy to receive information, so the more knowledge received ${ }^{(8)}$. Students are people who study in universities. Individuals with high education will be better able to apply clean and healthy life behavior than individuals with low education level.

Faculty is part of college where studying knowledge field which consists of several majors. Based on the field of science studied, students classified into health and non-health faculty students. More non-health faculty student suffered from hepatitis A than health faculty students. This is because health faculty students learn about the concept of illness, illness and ill behaviour more profound than non health student. So that the level of knowledge about the concept of illness and disease in health faculty students are better than that of non-health faculty students.

769 | Publisher: Humanistic Network for Science and Technology 
In characteristic variable there is immunization status factor. Immunization is a prevention program against infectious diseases that is applied by giving vaccines, so that a person is immune or resistant to the disease. The Health Promotion Center of the Ministry of Health (2010) also said that immunization is important to protect against hepatitis A disease, a person who does not get immunization tends to be exposed easily to hepatitis A disease. The risk of hepatitis A attack on someone who has not received hepatitis A immunization will be greater than the risk of someone who has already received hepatitis A immunization. Hepatitis A immunization is recommended for potential infected persons such as boarding / boardingers and those who frequently take snacks outside the home.

Analysis of the relationship between knowledge level with hepatitis A incidence in table 2 showed significant result. That means level of knowledge has influence on the hepatitis A incidence. Analysis of the relationship between personal hygiene variables and the incidence of hepatitis A in table 3 showed significant results. That means personal hygiene has influence on the hepatitis A incidence. While, the environmental sanitation variables has no influence on the hepatitis A incidence. Students' attitude in maintaining hygiene and health itself is poor, especially for the prevention of Hepatitis A. WHO (2013) states that Hepatitis A is transmitted through the feces or stools of patients infected with HAV, the spread is oral fecal through contaminated food. The transmission rates is high in poor hygiene and sanitation. Poor individual hygiene such as not washing hands after bowel movements and before eating caused hepatitis A virus entering the body when that person eating. Personal hygiene is a major preventive effort to prevent a person contracting hepatitis A disease. In Indonesia there is no detailed data about hepatitis A transmission risk factor, but allegdly because of HAV contaminated foods and low socioeconomic status.

\section{CONCLUSION}

Based on the results and discussion of research that has been done on the students of Jember university, it can be concluded that characteristics variables have no effect on the incidence of hepatitis A. Knowledge variable showed a significant results, that means knowledge has an effect on the incidence of hepatitis A. Personal hygiene is associated with the incidence of hepatitis A, while there is no relationship between sanitation and hepatitis A incidence. According to logistic regression analysis results, knowledge and personal hygiene variable are the most influential factors that can cause hepatitis A among students of Jember University.

\section{REFERENCES}

1. Horn T, Learned J. Hepatitis Virus dan HIV. 2005.

2. Kemenkes RI. Hepatitis Virus [Internet]. 2015. Available from: http://www.pusdatin.kemkes.go.id/article/view/15073000001/w-a-s-p-a-d-a-2-9-juta-lebih-pendudukindonesia-mengidap-hepatitis.html

3. Pertiwi AIP, Ramani A, Ariyanto Y. Mapping of Hepatitis A Risk with Geographic Information System (GIS) in Jember. 2014;2.

4. Dinkes Kab. Jember. Outbreak of Hepatitis A (Kejadian Luar Biasa Hepatitis A). Jember: Dinas Kesehatan Kabupaten Jember; 2003.

5. Sasoka DS, Satyabakti P. The Relationship Between Individual Hygiene and the Incidence of Hepatitis A in Student. Epidemiologi. 2014;2(3):331-41.

6. Hurlock. No Title. 2002.

7. Notoatmodjo S. Health Research Methods. 2010.

8. Wawan. Hepatitis A Virus. 2010. 